\title{
The Role of the Labour Market in Wealth Accumulation
}

\author{
Marcela Barčáková* \\ Alexander Dubček University, Department of Political Science, \\ Študentska 2, 911 50, Trenčin, Slovakia \\ marcela.barcakova@tnuni.sk
}

Nikola Šubová*

Faculty of Economics, Technical University of Kosice, Department of Finance, Němcovej 32, 01001 Košice, Slovakia

nikola.subova@tuke.sk

\begin{abstract}
:
Purpose and Originality: Our goal in this paper is to contribute to the professional public by analysing the set of criteria for success, or the failure of the Europe 2020 Strategy in the view of labour market. Our goal is to analyse the effect of labour market in the wealth accumulation because of the Strategy 2020 in two selected countries, namely Slovakia and Croatia.

Method: In our paper, we primarily used an econometrics method called simple linear regression, then we used comparative and descriptive methods that helped us to analyse the development of unemployment and employment rate in Slovakia and Croatia and compare them to these labour market indicators for the whole European Union. For the purposes of our analysis and our paper and for the better orientation, we bring in our paper definition of the most important notions mentioned in this paper, so we also used descriptive method. In our paper, therefore, we examine the trace of unemployment in correlation with the wealth rate in two selected countries.

Results: Our analysis confirm that the situation on labour market in both analysed countries influences the ability of households to accumulate wealth. Higher employment and lower unemployment rates are associated with greater wealth accumulation. We confirmed by the analysis that the employment rate of Slovakia has increased in the period, in 2018 while the employment rate of Croatia has been a little fluctuating. The employment rate of Croatia raised in 2018. As our results show, the employment rate of Slovakia has increased during the analysed period, while in Croatia this increasing has been smaller. Because of the global financial crisis, the employment rate of both countries decreased, but after these times, the strategies helped to create jobs and raised employment. The situation on the labour market evaluated by the unemployment rate has been almost the same. Although the employment of analysed countries has increased in the observed period, it is still under the employment rate of the European Union.

Society: Low unemployment is often associated with a high share of the wealth of the country and households. High unemployment rates and the associated slow economic growth, especially during and after the economic - financial crisis, have forced the European Union to create and modify programs to boost economic growth, increase employment, increase education through innovative approaches etc.

Limitations / further research: We consider this topic as important and interesting, and that is why we will continue our research after 2020. We want to do further research, how is the Strategy successful.
\end{abstract}

Keywords: employment rate, poverty, Strategy Europe 2020, Slovakia, Croatia. 


\section{Introduction}

Our goal in this paper is to contribute to the professional public by analysing the set of criteria for success, or the failure of the Europe 2020 Strategy in the view of labour market. Strategy Europe 2020 was accepted by the European Council in 2010 and focuses on the employment and growth of the European Union until 2020.

Our goal is to analyse the effect of labour market in the wealth accumulation as a result of the Strategy 2020 in two selected countries, namely Slovakia and Croatia. We chose Slovakia as a country that has been a member of the European Union (EU) since 2004. We chose Croatia as an example of the country that is the newest member of the EU since 2013. In this paper, we want to give examples of EU countries. We would like to point out whether and how the implementation and success of the Strategy 2020 depend on the time of EU membership and the country's operation.

For the better orientation, we bring in our paper definition of the most important notions mentioned in this paper.

\section{Theoretical framework}

Strategy Europe 2020 was endorsed by the Council of Europe in 2010. Its predecessors were the Strategies from 2000 and from 2005. The Lisbon Strategy of 2000 was the conception that should help to European union with the competitiveness and dynamic of the economy with a view to sustainable growth, a high level of employment and social cohesion. This Strategy, also known as the European Union Strategy for Growth and Jobs, was modified in 2005 to the Strategy of Growth and Jobs. The modification was caused due to the results of the previous strategy, which did not meet the expectations of the representatives of EU governments and states. In 2010, the Council of Europe endorsed a strategy to deliver growth and a high level of employment by 2020. In particular, policy coordination includes initiatives, multi-policy strategies, research, employment, education, social inclusion, energy, and the environment, as well as increased literacy of information technology, business, and industry (Government Office of the Slovak Republic, 2011).

The main goals of the Strategy Europe 2020 are to ensure growth and employment, which have been weakened as a result of the financial and economic crisis, and even stalled in some areas. The strategy, therefore, supports reforms to bring sustainable growth and a high level of employment that can lead to higher wealth accumulation. The document further states that growth should be intelligent, sustainable, and inclusive, through innovations, the ecology, competitive economy, and more stable employment and social cohesion (European Commission, 2010).

For summary, the main objectives of the Strategy are the following: 1. Increasing the employment of the population between 20 and 54 years to a minimum threshold of $75 \%$. 2 . Support Research and Development by investing 3\% of GDP. 3. Increase energy efficiency by $20 \%$ and increase renewables. It also aims to reduce greenhouse gases by at least $20 \%$. 4 . 
Promote education to increase the number of university graduates to at least $40 \%$ and reduce the proportion of early school leavers. 5. Reduce the number of people suffering from poverty by at least 20 million (European Commission, 2010).

Unemployed person and unemployment. The definition is given as follows: an unemployed person or persons who are between 15 and 74 years of age and meet three conditions simultaneously. The first condition is that during the reference week, they did not have any paid work; simultaneously they have to fulfill conditions, that during the last four weeks they were actively seeking a job, or they have already found the job and will start within 3 months. At the same time, they must meet the third condition such as the unemployed person is able to start working within two weeks (Eurostat, 2010)

Unemployment is an indicator that shows how many of the working population are unemployed. Those data are given in percentages.

Poverty as a concept can be defined in several ways. It is important to realize that poverty as such is a problem not only for less developed countries but also for economically developed countries. In our paper, we incline to the Council of Europe's definition of poverty in December 1984. This definition identifies poverty as "persons, families or groups of people whose resources (material, cultural and social) are so limited that they exclude them from minimally accepted lifestyles of states, in which they live" (The World Bank, 2002). We perceive this definition as the most appropriate for our paper, as it covers a wide range of cultural influences or material resources, leading to the definition of poverty in specific countries. Poverty can also be seen in terms of resources and access to resources such as health care, education, or employment.

European union in according to increase employment, increase social inclusion, and help with social affairs establish The Employment and Social Innovation program (EaSI program). This programme is an instrument for the European union which helps finance the calls to reach higher employment, more sustainable employment, social protection, and combating poverty and social exclusion.

The participation of the EU countries in this EaSI prograe depends a lot on the proposals to call and it has different results among the countries. How successful countries depend on a high level about themes and objectives of the particular proposals and calls. During the 2014 and 2018, there were 31 Employment and Social Innovation calls for proposals successful. Several points of view and aspects are important for successfully fulfill criteria. They are the following: eligibility criteria, the timing, possibilities, and requirements of partnerships, the period of implementation, and EU co-financing. EU indicates that the rate of successful calls of proposals during the year is increasing. It is mostly because of better targeting criteria and requirements, EU co-financing and the amount of money in the budget, etc.

Program EaSI is under European Commission. Within this program are including three programs which was during the years 2007 and 2013 separate. They are Progress, Eures, and 
Microfinancing Progress (MFSE). The budget for the $2014-2020$ years is 919. 469. 000 Euros. Progress was established to modernize employment policy and social policy. EURES is program for employment and staff mobility. MFSE program was established to enhance microfinancing and social entrepreneurs.

The relationship between the labour market and wealth accumulation is examined by various studies. Nowadays, there is an unemployment problem among young people all over the world and it affects the ability of young households to save money and accumulate wealth. It is necessary to create jobs and promote employment to increase the wealth and living standards of young people (Shauri, 2017).

Terajima (2006) highlights the importance of employment for wealth distribution mainly from the perspective of self-employment. The results of this study show that self-employed household members are able to accumulate a higher level of household wealth.

Sondhe (2013) also states that employment is a considerable factor in wealth accumulation because the economic future of each country is about creating new jobs. It helps to solve economic woes but the effect on the economy is only limited. On the other hand, job creation and higher employment lead to greater wealth accumulation. The effect of wealth is farreaching because it helps to spread human propensity and solve more economic problems. However, the relationship between wealth and employment is affected by other factors such as government transfers and taxation that increase the correlation between labour market and wealth (Yum, 2018).

Labour market should be evaluated by unemployment as well. A higher unemployment rate directly translates to a lower level of wealth while the unemployed person has lower ability to save Cooper, 2014).

\section{Method}

This paper is based on the analysis of the importance of labour market for the level of household wealth in Slovakia and Croatia. The country-level data used in the study was obtained from the European Commission database (Eurostat). Data set covered the period from 2002 to 2018 and included households in Slovakia and Croatia. Household wealth (in million euro) was represented by the difference between total assets and total liabilities of households coded nasa_10_f_bs (Eurostat, 2020a), while the labour market was characterised by employment (percentage of employed citizens aged from 15 to 64) and unemployment rate (percentage of unemployed citizens aged from 15 to 64) coded lfsa_ergan (Eurostat, 2020b) and lfsa_urgan (Eurostat, 2020c).

We primarily used an econometrics method called simple linear regression. Linear regression is an approach to modeling a relationship between variables used by many authors, such as Giavazzi and McMahon (2012), Semyonov and Lewin-Epstein (2013), Fessler et al. (2014), Chang et al. (2018). A simple linear regression model is given by the general equation: 


$$
Y_{i}=\beta_{0}+\sum_{i=1}^{k} \beta_{j} X_{i j}+\varepsilon_{i}
$$

where:

- $\mathrm{Y}_{\mathrm{i}}$ : explained variable (the level of household wealth);

$-\mathrm{X}_{\mathrm{ij}}$ : explanatory variables (employment and unemployment rate);

-i: number of observations, $\mathrm{i}=1,2, \ldots \mathrm{n}$;

$-\varepsilon$ : error term;

$-\beta_{0}$ : intercept of the regression coefficient;

$-\beta_{\mathrm{j}}$ : proxy the value of regression coefficient $\mathrm{j}$, for $\mathrm{j}=0,1,2, \ldots \mathrm{k}$.

We applied the linear regression model in both of the mentioned countries. Firstly, we formed two models for Slovakia. Explained (dependent) variable was represented by the level of household wealth. We used the employment rate as an explanatory (independent) variable in the first simple linear regression model and the unemployment rate in the second model. The same procedure was applied to the data from Croatia. There was a problem with crosssectional correlation in our models and therefore we used the variance-covariance matrix (Arrellano method) to estimate the results.

Besides econometric methods, we also used comparative and descriptive methods that helped us to analyse the development of unemployment and employment rate in Slovakia and Croatia and compare them to these labour market indicators for the whole European Union.

\section{Results}

First of all, we compared the development of employment and unemployment rate of Slovakia and Croatia with the employment and unemployment rate of the European Union (28). Graph 1 and Graph 2 describe the situation in the labour market.

As Grap 1 displays, the employment rate of Slovakia has increased in the period from $56.5 \%$ in 2002 to $67.6 \%$ in 2018 while the employment rate of Croatia has been a little fluctuating. It increased from 52,9\% in 2002 to $60 \%$ in 2008, but from this year, the rate was decreasing until 2013. In this year, the employment rate of Croatia was $52.5 \%$. The employment rate of Croatia raised from $52.5 \%$ in 2013 to $60.6 \%$ in 2018. Although the employment of analysed countries has increased in the observed period, it is still under the employment rate of the European Union. 


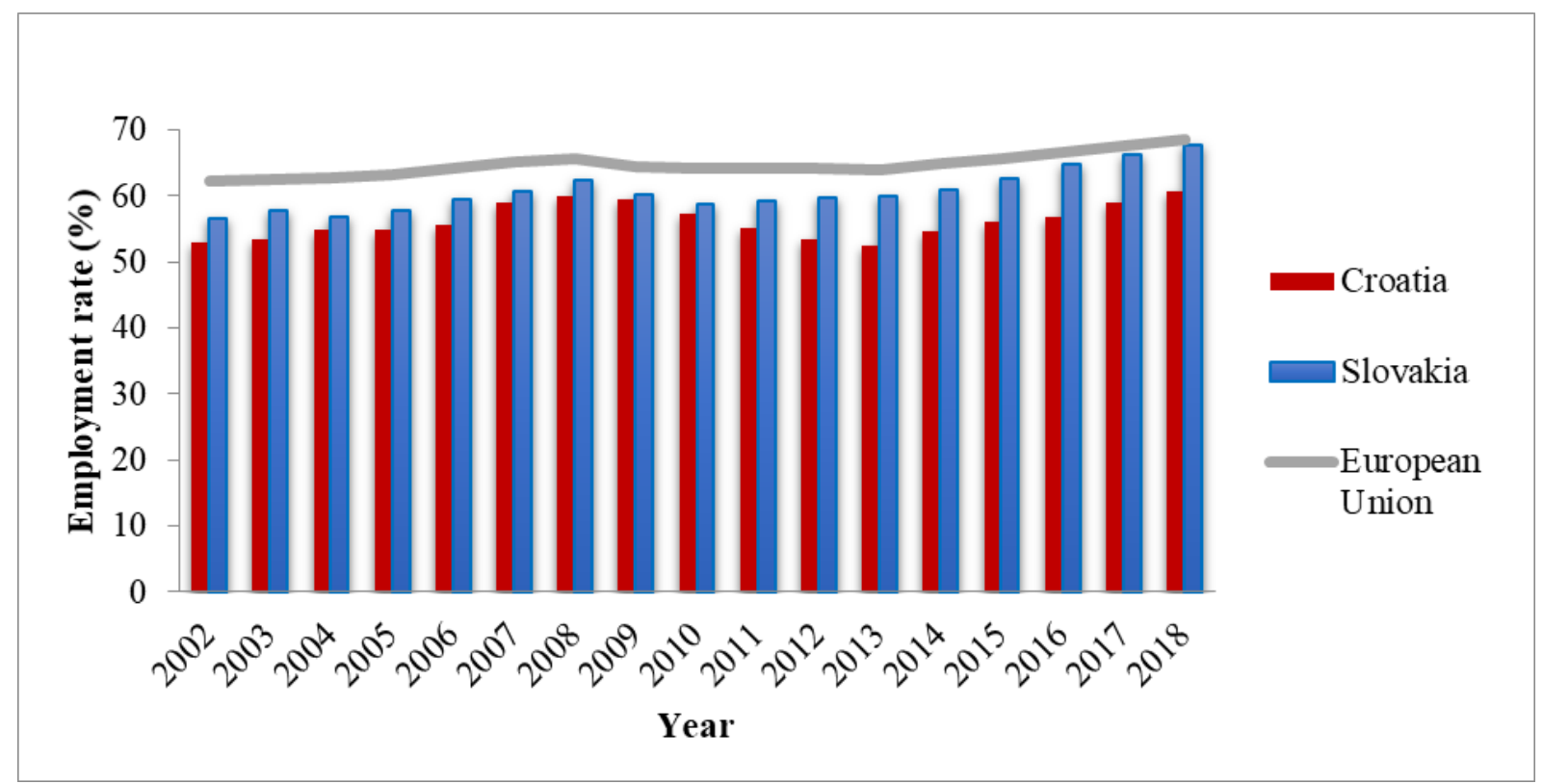

Figure 1. Development of the employment rate (in \%)

Source: own processing

The unemployment rate has changed significantly in both analysed countries. At the beginning of the observed period, the unemployment rate was higher in Slovakia but decreased by $6.6 \%$ to 2009. After this year, the unemployment rate of Slovakia raised again but from 2014 (the unemployment rate was 13,2 \%) has decreased to $6.6 \%$. The unemployment rate in Croatia decreased from $15.4 \%$ in 2002 to $8.7 \%$ in 2008. From this year, the unemployment rate of Croatia was increasing until 2014 and then begin to decrease. The level of unemployment rate in Croatia was $8.5 \%$ in 2018 and it indicates that it was higher than in Slovakia. The unemployment rate of these countries was almost under the European Union unemployment rate until 2012 when the unemployment rate of Croatia sharply increased and crossed the EU unemployment rate significantly.

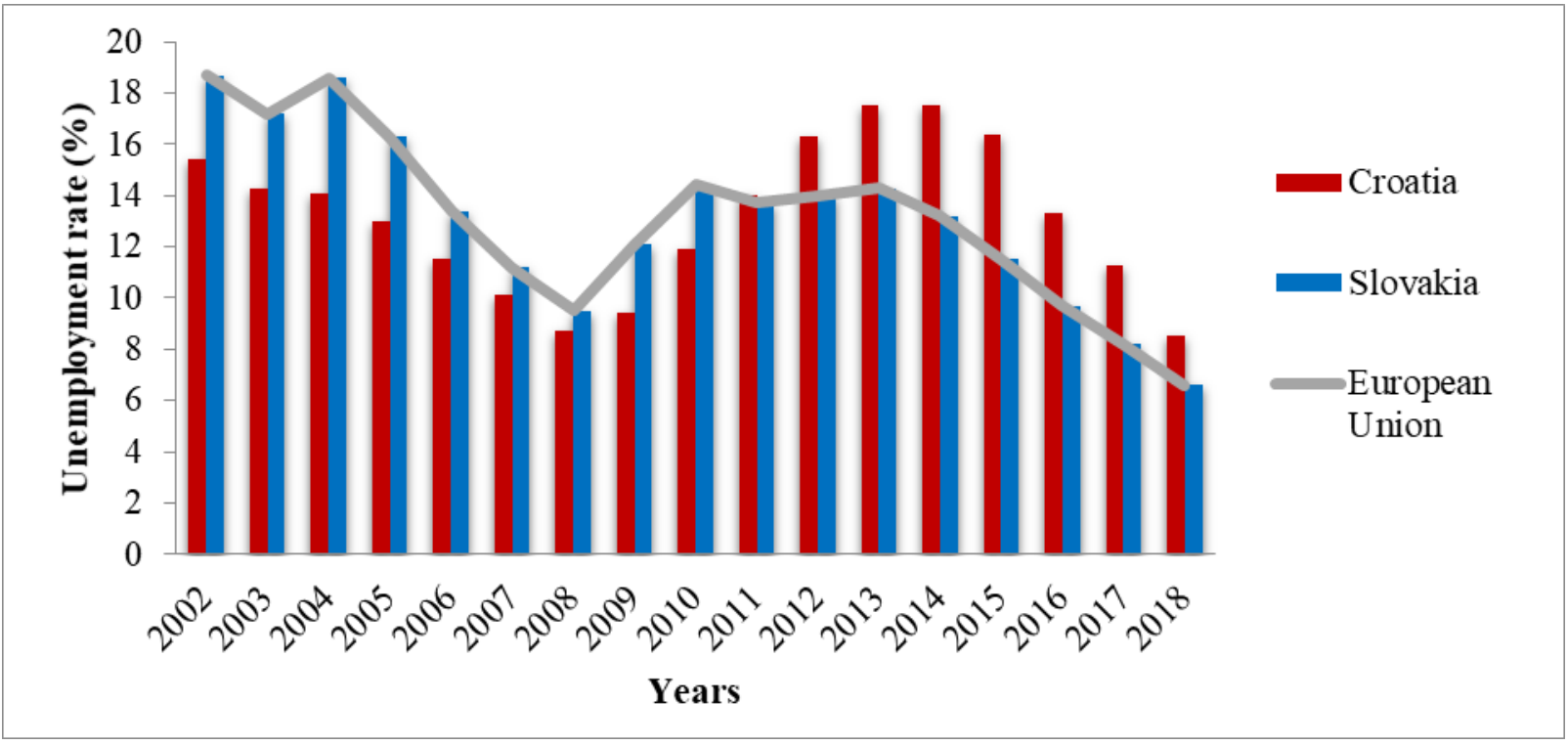

Figure 2. Development of the unemployment rate (in \%); Source: own 
The results of simple linear regression models are presented in Table 1 and Table 2. Table 1 displays that labour market represented by employment and unemployment rate is important for the wealth accumulation of Slovak households. A higher employment rate leads to a higher level of household wealth $(\alpha=0.001)$. If the employment rate increases by one percent, the level of household wealth will increase by 3138.83 euros. On the other hand, increasing the unemployment rate causes a decrease in household wealth $(\alpha=0.001)$. One percent increase in the unemployment rate will decrease the wealth by 2653.01 euros.

Table 1. The importance of labour market for household wealth in Slovakia

\begin{tabular}{lcc}
\hline Regression coefficient & Estimate & P-value \\
\hline Employment rate & 3138.83 & $4.45 \mathrm{e}-05 \quad * * *$ \\
Unemployment rate & -2653.01 & $9.073 \mathrm{e}-09 * * *$
\end{tabular}

Note: $* * *$ significant at $0,1 \%$ level $(\alpha=0,001)$; Source: own

The labour market is important for the level of household wealth in Croatia as well. The employment rate increases household wealth $(\alpha=0.01)$ and in contrast to that, the higher unemployment rate decreases the level of wealth $(\alpha=0.001)$. One percent increase in the value of employment rate leads to greater wealth by 1563.83 euro and a one percent higher unemployment rate causes a decline in wealth by 117.76 euros.

Table 2. The importance of labour market for household wealth in Croatia

\begin{tabular}{lcll}
\hline Regression coefficient & Estimate & P-value & \\
\hline Employment rate & 1563.83 & $<2.2 \mathrm{e}-16$ & $* * *$ \\
Unemployment rate & -117.76 & $<2.2 \mathrm{e}-16 \quad * * *$ \\
\hline
\end{tabular}

Note: $* * *$ significant at $0.1 \%$ level $(\alpha=0.001)$; Source: own processing

\section{Discussion}

One of the main aims of the strategies mentioned in this paper (Strategy for Growth and Jobs, The Employment and Social Innovation programme, Europe 2020) is to ensure high employment that has been weakened as a result of the last global financial crisis. These strategies focus on the plans to create jobs and bring a higher employment rate that is connected with greater economic growth and the level of wealth of households.

As our results show, the employment rate of Slovakia has increased by $11.1 \%$ in the analysed period. The increase in the employment rate of Croatia has been smaller, $8.1 \%$ between the years 2002-2018. As a consequence of the global financial crisis, the employment rate of both countries decreased, but after these times, the strategies helped to create jobs and raised 
employment. The situation on the labour market evaluated by the unemployment rate has been almost the same.

Results of simple linear regression displayed in Table 1 confirm that the situation on labour market in both analysed countries influences the ability of households to accumulate wealth. Higher employment and lower unemployment rates are associated with greater wealth accumulation. These results are in line with authors of other studies (for example Terajima, 2006; Bauer et al., 2011; Shauri, 2017), who state that higher employment leads to greater wealth accumulation. A higher employment rate raises wealth accumulation while the economy of each country is about job creation. Higher employment is associated with the greatest economic growth that also helps to promote wealth accumulation (Sondhe, 2013). These results agree not only with authors of other studies but also with strategies mentioned in this paper.

\section{Conclusion}

The Europe 2020 strategy followed the Lisbon strategy the European Union strategy for growth and employment. The main goal of the strategy Europe 2020 is to bring the growth of countries and the employment that decreased as a consequence of the last economic crisis in 2008 .

The main contribution of this paper is a detailed analysis of the aims of strategies that should lead to job creation associated with GDP growth and wealth accumulation, and also analysis of the situation on labour market in two selected countries and its relationship with the level of wealth. The aim of our paper was to analyse the results of strategy Europe 2020 in two selected countries, Slovakia and Croatia. Slovakia has been a member of the European Union since 2004, while Croatia is the newest member of the European Union (since 2013). Before the analysis, we defined the most important terms that were necessary to know, such a $\mathrm{s}$ unemployment and poverty. We described The Employment and Social Innovation programme (EaSI programme), whose main goal is the financing of the calls to reach higher employment, more sustainable employment, social protection, and combating poverty and social exclusion.

Our analysis was based on the data obtained from the European Commission database in the period from 2002-2018. To observe the development of indicators of labour market we used comparative and descriptive methods, while the effect of employment and unemployment on the level of household wealth was analysed by linear regression.

The results of our analysis showed that the employment rate was raising the whole period from 2002 to 2018, while the employment rate in Croatia was fluctuating and was raising from 2013 to the end of the period. The second indicator of labour market, the unemployment rate was oscillating also in Slovakia. The unemployment rate was decreasing from 2004 (but there was a little increase from 2008 to 2010). The unemployment rate in Croatia sharply increased between 2008 and 2013. From 2013, the unemployment rate in Croatia was 
decreasing. The analysis of selected labour market indicators showed that the European Union membership played an important role mainly in the case of unemployment, which decreased after states joined the European Union.

The next part of the analysis was focused on the importance of the labour market for the level of household wealth that showed that a better situation in the labour market leads to a higher level of household wealth. Higher employment rates and lower unemployment rates are considered to be important goals of programs and strategies of the European Union with a purpose to increase the growth and improve the position of countries.

\section{References}

1. Cooper, D. (2014). The Effect of Unemployment Duration on Future Earnings and Other Outcomes [online]. Boston: Federal Reserve Bank of Boston Working Paper No. 13-8. Available at:

https://www.bostonfed.org/publications/research-department-working-paper/2013/theeffect-of-unemployment-duration-on-future-earnings-and-other-outcomes.aspx

2. European Commission. (2010). EUROPE 2020. A strategy for smart, sustainable and inclusive growth [online]. Brussel: European Commission. Available at:

https://ec.europa.eu/eu2020/pdf/COMPLET\%20EN\%20BARROSO\%20\%20\%20007\%2 0-\%20Europe\%202020\%20-\%20EN\%20version.pdf

3. Eurostat. (2010). Unemployment definition [online]. Available at: https://ec.europa.eu/eurostat/statistics-explained/index.php/Glossary:Unemployment

4. Eurostat. (2020a). Financial balance sheets [online]. Luxembourg, Luxembourg: Eurostat. Available at:

https://appsso.eurostat.ec.europa.eu/nui/show.do?dataset=nasa_10_f_bs\&lang=en\&fbclid =IwAR2Az8u7UInoGs-GcOi08igUCBeafviUQDTyESmnFXScDrqG-k7SO0EvwuQ

5. Eurostat. (2020b). Employment rates by sex, age and citizenship (\%) [online]. Luxembourg, Luxembourg: Eurostat. Available at:

https://appsso.eurostat.ec.europa.eu/nui/show.do?dataset=lfsa_ergan\&lang=en\&fbclid=I wAR1fmtYO52eP4PdFdKucSeWcL5trBDzAE34u7tdlTq9E2eGdJNsxzx9yp7Q.

6. Eurostat. (2020c). Unemployment rates by sex, age and citizenship (\%) [online]. Luxembourg, Luxembourg: Eurostat. Available at:

https://appsso.eurostat.ec.europa.eu/nui/show.do?dataset=lfsa_urgan\&lang=en\&fbclid=I wAR3X_bU81B9Ev8gqMVrt6TYIslF98LSnFcFxA4sQc-2nZcP4Q4ASiCv6sKo.

7. Fessler, P., Lindner, P., Segalla, E. (2014). Net wealth across the Euro area: Why household structure matters and how to control for it [online]. ECB Working Paper Series, No. 1663. Available at: https://www.ecb.europa.eu/pub/pdf/scpwps/ecbwp1663.pdf

8. Giavazzi, F., McMahon, M. (2012). The household effects of government consumption. NBER Working Paper No. 17837. DOI: 10.3386/w17837.

9. Government Office of the Slovak Republic. (2011). Stratégia Európa 2020 [online]. Slovak Republic: Government Office of the Slovak Republic. Available at: https://www.eu2020.gov.sk/strategia-europa-2020

10. Semyonov, M., Lewin-Epstein, N. (2013). Ways to Richness: Determination of Household Wealth in 16 Countries. European Sociological Review, 29, 6, s. 1134-1148. DOI: org.eres.qnl.qa/10.1093/esr/jct001. 
11. Shauri, H. (2017). Youth Unemployment in Kenya: Towards and Exploratory Employment and Wealth Creation Framework [online]. In Project: Salavage Kenya. Available at:

https://www.researchgate.net/publication/319329742_Youth_Unemployment_in_Kenya_ Towards_an_Exploratory_Employment_and_Wealth_Creation_Framework.

12. Sondhe, R. S. (2013). Wealth Creation vs. Job Creation. Why Creating Jobs Isn't the Real Answer to Our Economic Problems [online]. Available at:

http://www.probizwriters.com/Ratanjit\%20wealth\%20v\%20jobs\%20(3rd\%20Draft\%2043-13).pdf

13. Terajima, Y. (2006), Education and Self-Employment: Changes in Earnings and Wealth Inequalities. Bank of Canada, Working Paper, No 40. ISSN: 1192-5433.

14. The World Bank. (2001). Slovak Republic. Living standards, Employment, and Labor Market Study [online]. The World Bank Report No 22351, 193p. Available at: http://documents.worldbank.org/curated/en/864281468776769918/pdf/multi0page.pdf

Marcela Barčáková is an internal PhD candidate at Department of Political Science at Trenčín University of Alexander Dubček in Trenčín, Slovakia. She studied Master degree at University of Zagreb, Croatia with the thesis: Croatia and its accession to the European union. Her main focus is European integration and Western Balkans.

$* * *$

Nikola Šubová in internal PhD candidate at Technical University of Kosice, Faculty of Economics, Department of Finance. She is also a graduate of Technical University of Kosice, Faculty of Economics. The main research areas are household finances, well- being and welfare. She put her attention on wealth and financial vulnerability of households using various econometric methods. The subjects she teaches as a $\mathrm{PhD}$ candidate are focused on finances: Money and finances, Public finance and Finances of territorial self- government units.

\section{Povzetek: \\ Vloga trga dela v kopičenju bogastva}

Namen in izvirnost: Naš cilj $\mathrm{v}$ tem prispevku je prispevek strokovni javnosti z analizo nabora meril za uspeh ali neuspeh Strategije Evropa 2020, glede na trg dela. Naš cilj je analizirati učinek trga dela na kopičenje bogastva, zaradi Strategije 2020 v dveh izbranih državah, in sicer na Slovaškem in Hrvaškem.

Metoda: V našem prispevku smo v prvi vrsti uporabili ekonometrično metodo, imenovano enostavno linearno regresijo, nato smo uporabili primerjalne in opisne metode, ki so nam pomagale analizirati razvoj stopnje brezposelnosti in zaposlenosti na Slovaškem in Hrvaškem, ter jih primerjati s temi kazalniki trga dela za celotno Evropsko unijo. Za potrebe analize in našega prispevka, ter za boljšo orientacijo, v naš prispevek vnašamo definicijo najpomembnejših pojmov, omenjenih $\mathrm{v}$ tem prispevku, zato smo uporabili tudi opisno metodo. $\mathrm{V}$ našem prispevku zato preučujemo sled brezposelnosti v povezavi s stopnjo bogastva $\mathrm{v}$ dveh izbranih državah.

Rezultati: Naša analiza potrjuje, da razmere na trgu dela v obeh analiziranih državah vplivajo na sposobnost gospodinjstev za kopičenje bogastva. Večja zaposlenost in nižja stopnja brezposelnosti sta povezana $\mathrm{z}$ večjim nabiranjem bogastva. $\mathrm{Z}$ analizo smo potrdili, da se je stopnja zaposlenosti na Slovaškem v letu 2018 povečala, medtem ko je stopnja zaposlenosti na Hrvaškem nekoliko nihala. Stopnja zaposlenosti na Hrvaškem se je v letu 2018 dvignila. Kot kažejo naši rezultati, se je stopnja zaposlenosti Slovaške $\mathrm{v}$ analiziranem obdobju povečala, na Hrvaškem pa je bilo to povečanje manjše. Zaradi svetovne finančne krize, se je stopnja zaposlenosti v obeh državah znižala, a so v tem času strategije pomagale ustvariti delovna mesta in povečati zaposlenost. 
Avgust / August 2020, leto / year 5, številka / number 3, str. / pp. 174-184.

Razmere na trgu dela, ocenjene s stopnjo brezposelnosti, so bile skoraj enake. Čeprav se je zaposlenost $\mathrm{v}$ analiziranih državah $\mathrm{v}$ opazovanem obdobju povečala, je še vedno pod stopnjo zaposlenosti v Evropski uniji.

Družba: Nizka brezposelnost je pogosto povezana $\mathrm{z}$ visokim deležem bogastva države in gospodinjstev. Visoke stopnje brezposelnosti in s tem povezana počasna gospodarska rast, zlasti med gospodarsko in finančno krizo, so prisilili Evropsko unijo k oblikovanju in spreminjanju programov za pospeševanje gospodarske rasti, povečanje zaposlenosti, povečanje izobraževanja $\mathrm{z}$ inovativnimi pristopi itd.

Omejitve / nadaljnje raziskave: Menimo, da je ta tema pomembna in zanimiva, zato bomo raziskavo nadaljevali tudi po letu 2020. Nadaljnje raziskave želimo narediti o tem, kako uspešna je strategija.

Ključne besede: stopnja zaposlenosti, revščina, Strategija Evropa 2020, Slovaška, Hrvaška.

Copyright (c) Marcela BARČÁKOVÁ, Nikola ŠUBOVÁ

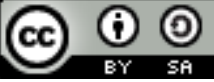

Creative Commons License

This work is licensed under a Creative Commons Attribution-ShareAlike 4.0 International License. 